\title{
PEMBERDAYAAN MASYARAKAT HUKUM ADAT (MASYARAKAT DESA) DALAM MENDUKUNG PROGRAM EKONOMI KREATIF DESA SESUAI UU DESA
}

\author{
Aartje Tehupeiory \\ aartjetehupeiory@gmail.com \\ Universitas Kristen Indonesia, Jakarta, Indonesia
}

\begin{abstract}
For the empowerment of village communities in supporting the Village Creative Economy Program, which is to nd creative and innovative thinking models to build villages in an innovative model of empowering communi-ties in poverty reduction given to rural communities through educational innovations, innovations in the utiliza-tion of vacant land, traditional market management innovations, innovation village based or village. a quality community was formed in the rural areas to provide digital education for business development and community empowerment to help community businesses and micro and small businesses.
\end{abstract}

Keywords: village community empowerment, village creative economy

\section{Pendahuluan}

Pasal 33 Undang-Undang Dasar 1945 merupakan pesan moral dm pesan budaya dalam konstitusi Republik Indonesia di bidang kehidupaa ekonomi.Pasal ini bukan sekadar memberikan petunjuk tentang susu-nan perekonomian dan wewenang negara mengatur kegiatan perekonomian, melainkan mencerminkan citacita, suatu keyakinan yang dipegang teguh serta diperjuangkan secara konsisten oleh para pimpinan pemerintahan.Pesan konstitusional tersebut tampak jelas, bahwa yang dituju adalah suatu sistem ekonomi tertentu, yang bukan ekonomi kapitalistik (berdasar paham individualisme), namun suatu sistem ekonomi berdasar kebersamaan dan berdasar atas asas kekelu$\operatorname{argaan} .1$

Berdasarkan pada Pasal 33 UUD 1945 maka dalam rangka mewujudkan pemberdayaan masyarakat desa sebagai upaya dalam mengembangkan kemandirian dan kesejahteraan masyarakat dengan meningkatkan

1 Herman Soewardi, Koperasi (Suatu Kumpulan Makalah), (Bandung: (kopin, 1989), hIm.413).dalam Buku Diskursus Hukum untuk Kesejahteraan Rakyat, Tim Penulis ILUNI S-3 FH-UI, Jakarta, Kencana 2019 hlm. 190. pengetahuan, sikap, keterampilan, perilaku, kemampuan, kesadaran, serta memanfaatkan sumber daya melalui penetapan kebijakan, program, kegiatan, dan pendampingan yang sesuai dengan esensi masalah dan prioritas kebutuhan masyarakat Desa.Ini diatur dalam Undang - Undang Nomor 6 Tahun 2014 tentang Desa. Ini mempunyai makna bahwa pemberdayaan masyarakat Desa merupakan pendekatan seluruh aspek kehidupan masyarakat yang bermotifkan pemandirian mampu membangkitkan kemampuan untuk meningkatkan kualitas hidup masyarakat yang mengacu pada cara berpikir, bersikap, berperilaku untuk maju. Dengan kata lain esensi pemberdayaan masyarakat Desa yaitu pendayagunaan sumber daya (potensi) lokal dengan meningkatkan partisipasi, kepedulian semua pihak untuk kemandirian/ berdikari.

Korelasi dengan hal diatas, tidak bisa di lepas-kan dari Desa, adalah kesatuan masyarakat hukum yang memiliki batas wilayah yang berwenang untuk mengatur dan mengurus urusan pemerintahan, kepentingan masyarakat setempat berdasarkan prakarsa masyarakat, hak asal usul, dan/atau hak tradisional 
yang diakui dan dihormati dalam sistem pemerintahan Negara Kesatuan Republik Indonesia (Undang-undang Nomor 6 Tahun 2014 Pasal 1). Ini bermakna Desa dan Desa Adat memiliki fungsi pemerintahan, keuangan Desa, pembangunan Desa, serta mendapat fasilitasi dan pembinaan dari pemerintah Kabupaten/Kota. Da-lam posisi seperti ini, Desa dan Desa Adat mendapat perlakuan yang sama dari Pemerintah dan Pemerintah Daerah. Oleh sebab itu, di masa depan Desa dan Desa Adat dapat melakukan perubahan wajah Desa dan tata kelola penyelenggaraan pemerintahan yang efektif, pelaksanaan pembangunan yang berdaya guna, serta pembinaan masyarakat dan pemberdayaan masyarakat di wilayahnya.

Menurut Jaringan Pembela Hak-Hak Masyarakat Adat (JAPHAMA), masyarakat adat adalah kelompok masyarakat yang memiliki asal-usul leluhur (secara turun-temurun) di wilayah geografis tertentu, serta memiliki sistem nilai, ideologi, ekonomi, politik, sosial, dan budaya sendiri.2 Sementara itu, Kongres masyarakat adat I pada tahun 1999 mendefinisikan masyarakat adat sebagai komunitas-komunitas yang hidup berdasarkan asal-usul leluhur secara turun temurun di atas suatu wilayah adat, yang memiliki kedaulatan atas tanah dan kekayaan alam, kehidupan sosial budaya, yang diatur oleh hukum adat dan lembaga adat yang mengelola keberlangsungan kehidupan masyarakatnya.z Dalam pencarian definisi itu, Pelapor Khusus PBB tentang masalah Diskriminasi terhadap Masyarakat Adat mengusulkan sebuah definisi sebagai berikut:

"Masyarakat, rakyat dan bangsa pribumi adalah mereka, yang karena telah memiliki kesinambun-gan historis dengan masyarakat pra-penaklukan dan prapenjajahan Barat yang telah berkembang di dalam wilayah mereka, menganggap diri mereka itu berbeda dari golongan-golongan lain dalam masyarakat yang sekarang ada dalam wilayah itu, atau bagian darinya. Sekarang ini mereka merupakan kelompok masyarakat

2 Definisi Jaringan Pembelaan Hak-Hak Masyarakat Adat-JAPHAMA yang dirumuskan di Tana Toraja tahun 1993

3Definisi yang dihasilkan dalam Kongres Masyarakat Adat Nusantara I pada tahun 1999 di Jakarta.Kongres itulah yang kemudian melahirkan Aliansi Masyarakat Adat Nusantara (AMAN). yang tidak dominan, namun tetap bertekad untuk menjaga, mengembangkan dan menurunkan kepada generasi-generasi di masa mendatang, wilayah nenek moyang mereka, dan jati diri etnis mereka, sebagai dasar dari kelanjutan eksistensi mereka sebagai bangsa, sesuai dengan pola budaya, lembaga kemasyarakatan dan sistem hukum mereka sendiri".

Dari definisi-definisi yang ditawarkan di atas paling tidak ada beberapa hal yang menjadi penanda dari apa yang disebut dengan masyarakat adat:

1. Kelompok masyarakat / komunitas 4

2. Memiliki kesamaan asal-usul leluhur

3. Memiliki wilayah yang tertentu (wilayah adat/ ulayat)

4. Memiliki hukum adat dan lembaga adat

5. Memiliki sistem nilai, ideologi, ekonomi, politik, sosial, dan budaya sendiri

6. Pada awalnya mereka berdulat atas tanah dan kekayaan alam, kehidupan sosial budaya.Namun ada banyak factor yang membuat kedaulatan mereka rusak, seperti penjajahan,arus investasi yang merusak, dan sebagainya.

7. Kelompok masyarakat yang tidak dominan dalam masyarakat

8. Berorientasi kepada kehidupan di masa yang akan datang (keadilan bagi generasi di masa depan).

Sementara itu Aliansi Masyarakat Adat Nusan-tara (AMAN) memberikan definisi Masyarakat Adat sebagai komunitas yang memiliki asal-usul leluhur secara turun temurun yang hidup di wilayah geografis tertentu, serta memiliki sistem nilai, ideologi ekonomi, politik, budaya dan sosial yang khas.5 Sedangkan menurut ahli hukum adat Ter Haar, masyarakat hukum adat merupakan masyarakat yang memiliki kesamaan wilayah (territorial), keturunan (geneologis), serta wilayah dan keturunan (territorial-geneologis), sehingga terdapat keragaman bentuk masyarakat adat dari suatu tempat ke tempat lain.6

4Laksanto Hutomo, Hukum Adat, Depok, Rajawali Pers 2017, hlm.134.

5Bandingkan dengan Bagir Manan, Suatu Kaji Ulang Atas undangUndang No.5 Tahun 1974, Makalah Pro Justitia No.2 Tahun IX April 1991, hlm.18.

6 http://www.aphi-net.com/konflik lisman vl 15/pdf/ 300masv-FI- 
Berdasarkan pengertian tersebut, maka dapat ditarik pemahaman bahwa karakteristik otonomi yang berada dalam lingkup Masyarakat Adat tidak lain menyangkut kesamaan sistem nilai yang didasarkan pada aspek kewilayahan maupun keturunan, sehingga mengakibatkan substansi dari otonomi masyarakat adat tersebut berbeda-beda antara satu dengan lain-nya. Lahirnya UU PPMA, selain berupaya untuk memberikan kepatuhan hukum atas perlindungan kelangsungannya juga berupaya untuk memelihara kebhineka-an-nya di tingkat lokal. Dengan demikian, keberadaan masyarakat adat merupakan salah satu penopang dari keutuhan NKRI memalui penguatan hakhak mereka dalam sistem negara. Dalam konteks ini, maka keberadaan masyarakat adat akan menjadi keunikan tersendiri dalam negara.

Di masa depan Desa dan Desa Adat sebagai ujung tombak pemerintahan terbawah memiliki otonomi dalam mengatur pembangunan untuk mensejahterakan rakyatnya.Ini dapat melalui Sektor ekonomi kreatif berbasis desa yang menjadi gagasan pinggiran dapat mendukung program ekonomi kreatif desa. Oleh kar-ena itu menjadi masalah masyarakat sering kali hanya terfokus saja pada dana desa yang bersumber dari APBN saja, namun yang terpenting adalah proses pem-berdayaan masyarakat desanya. Dengan adanyaPeran masyarakat hukum adat dan pengelolaan hak ulayat diharapkan mendukung program ekonomi kreatif desa.Selama ini basis perekonomian nasional banyak ditopangoleh ekonomi kecil yang berbasis desa.Di In-donesia Desa-desa memiliki kreativitas tinggi sehingga gagasan desa kreatif dapat dikembangkan. Desa bisa meningkatkan nilai tambah (add value) sumber daya alam yang mereka miliki secara kreatif untuk menam-bah pendapatan masyarakat desa, bahkan dalam dalam jangka panjang akan mengurangi urbanisasi.Disinilah perlu pentingnya pemberdayaan masyarakat desa ( hukum adat) dalam mendukung Program ekonomi Kreatif Desa sesuai dengan UU Desa.

NALE.pdf

\section{Pembahasan}

Dalam Pasal 78 (UU Desa) Pembangunan Desa bertujuan meningkatkan kesejahteraan masyarakat Desa dan kualitas hidup manusia serta penanggulangan kemiskinan melalui pemenuhan kebutuhan dasar, pembangunan sarana dan prasarana Desa, pengembangan potensi ekonomi lokal, serta pemanfaatan sumber daya alam dan lingkungan secara berkelanjutan. Ini bermakna bahwa pembangunan desa mempunyai tujuan meningkatkan kesejahteraan masyarakat Desa dan kualitas hidup manusia serta penanggulangan kemiskinan melalui penyediaan pemenuhan kebutuhan dasar, pembangunan sarana dan prasarana, pengembangan potensi ekonomi lokal, serta pemanfaatan sumber daya alam dan lingkungan secara berkelanjutan. Untuk itu, Undang-Undang ini menggunakan 2 (dua) pendeka-tan, yaitu 'Desa membangun' dan 'membangun Desa' yang diintegrasikan dalam perencanaan Pembangunan Desa.

Melalui pemberdayaan masyarakat Desa diharapkan mampu membawa perubahan nyata sehingga harkat dan martabat mereka pulih kembali. Pem-berdayaan masyarakat merupakan pendekatan yang memperhatikan seluruh aspek kehidupan masyarakat dengan sasaran seluruh lapisan masyarakat, bermotifkan kemandirian (keberdikarian), sehingga mampu membangkitkan, kemampuan self-help, untuk meningkatkan kualitas hidup masyarakat (modemisasi) yang mengacu pada cara berpikir, bersikap, berperi-laku untuk maju. Bidang pemberdayaan merupakan titik strategis yang harus diperbarui dan diperluas. Dengan demikian esensi pemberdayaan masyarakat di pedesaan adalah pendayagunaan sumberdaya (potensi) lokal,meningkatkan partisipasi, memupuk kepedulian semua pihak untukkemandirian(berdikari) masyarakat.

Apa itu ekonomi kreatif? Ekonomi kreatif berkembang sebagai hasil dari kegiatan mengolah kreasi akal budi menjadi produk bernilai tambah ekonomi tinggi. Pelaku utamanya adalah manusia-manusia kreatif yang mampu mengubah ide menjadi produk bernilai ekonomi tinggi.Jadi, bertahan atau tumbuhnya ekono- 
mi kreatif tak lepas dari kreativitas dan inovasi yang mampu diciptakannya. Istilah ekonomi kreatif muncul pada tahun 2005an. Ada 15 sektor yang bisa mendorong laju ekonomi kreatif di Indonesia yaitu perikanan, arsitektur, seni rupa kerajinan, desain fasyen, film, music, seni pertunjukan, penerbitan, dan pengembangan (litbang), software komputer, alat permainan, radio/ televisi, dan video game.Laju ekonomi kreatif ditentukan oleh kemampuan masyarakat dalam mengelola pengetahuannya.Futurolog Tofler berpendapat bahwa ekonomi kreatif hanya menunjukkan pengetahuan mulai tumbuh.Tofler sendiri percaya bahwa era pertanian, era industrialisasi.Di sejumlah negara, ekonomi kreatif justru mendorong sektor pertanian dan sektor industri untuk terus tumbuh dan berinovasi.7

Membangun desa dengan cara yang kreatif dan inovatif dapat dilakukan dengan membuat karya-karya yang menarik. Berbagai potensi yang ada didesa sangat mung $\mathrm{n}$ apat dikembangkan dan dapatmewu-judkan kegiatan berbasis Usaha EkonomiMasyarakat jika dikemas dengan cara yang kreatif daninovatif. Misalnya bagaimana jika produk makanan ringan yangselama ini hanya dibuat untuk konsumsi rumah tanggabisa diproduksi dengan kemasan yang menarik sertamemiliki izin dari Dinas Kesehatan danPengawas Obat dan Makanan (BPOM) untuk bisa dijualdi pasar tradisional atau supermarket. Selama Ini produk-produk desa sebagian besar hanya sebagaipemasok bahan baku saja tidak sampai menjadi produkjadi. Begitu juga dengan potensi keindahan alam desa, dapatdikemas secara kreatif dan inovatif den an membuatkonsep desa wisata, di mana rumah -rumah masyarakat desa dapat dijadikan homestay untuk para wisatawanmenginap. Namun, untuk mewujudannya dibutuhkan strategi pemasaran, seperti dibuatnya program-programpromosi untuk memperkenalkan pa-ket wisata yang ada di desa, baik secara online maupun ofline.Bumdesa bisa membuat program atau kegiatan di desa sebagai daya Tarik wisatawan.

Dengan begitu, jika berani untuk mencoba hal baru yang kreatif daninovatif,maka akan banyak usaha

7 www.kombinasi.net/kembangkan-ekonomi-kreatif-brbasis-desa/ kreatif yang bisa tumbuh di desa, apalagi jika usaha tersebut didukungoleh pemerintah dan universitas untuk memberikanprogram-program pelatihan keterampilan daneativitas bagi anak-anak muda di desa.

Tentunya untuk mencapai itu semua dibutuhkankeberanian.Mampu mengidentifikasikan masalah, lebih sering mencoba jika gagal, mampu berkompetensi, dan mampu berpikir di luar kebiasaan.Serta untuk dapatmemiliki ilmu pengetahuan yang luas, salah satunyaseperti internet (Interconnection Networking)yang dapat membantu anak muda yang cerdas danterampil untuk belajar dan mencari informasi tentangindustri kreatif agar dapat dikembangkan di desa.

Salah satu gerakan ekonomi kreatif adalah gerakan 'satu desa satu produk' atau one village one product (OVOP).8Gerakan OVOP telah menarikperhatian dari daerah yang berpenghasilan rendah yang tidak dapat menarik industri teknologi tinggi dan juga dan orangorang yang bekerja di bidang pengentasan kemiskinan dan masalah sosial.Gerakan ini merekomendasikan penduduk yang tinggal di daerah-daerah tersebut untukmenggunakan sumber daya lokal yang diproses dan dikemas sedemikian rupa agar bisa dibawa dan bersaing di pasar.Konsep OVOP dan Ekonomi Kre-atif menempatkan pembangunan dan pengembangan SDM sebagai faktor penting.Sasaran yang dituju OVOP adalah produk lokal yang berorientasi global dengan pendekatan komunal.Sementara itu, ekonomi kreatif menggunakan pendekatan individual. OVOP mengedepankan nilai tambah atas produk ang sudah ada smentara ekonomi kreatif melakukan pemba-ruan atas produk atau jasa yang telah ada atau justru menghadirkan produk dan jasa yang benar-benar barn dalam suatu proses inovatif.»Perbedaan keduanya bisa dijembatani dengankebijakan politik pemerintah yam kondusif. Tumpang tindih dan "perebutan wewenang" menangani kedua potensi kreatif masyarakat justru akan mematikan jalan menuju Indonesia sejahtera, adil dan makmur.

Sebagai contoh Sagu atau Metroxylon sagu Roth merupakan salah satu makanan pokok masyarakat

8www. Berdesa.com/produk-desa-ekonomi-kreatif/ 9 Ibid 
Papua yang erat kaitannya dengan budaya masyarakat setempat atau kearifan lokal.Bagi masyarakat Papua, sagu adalah makanan pokok salah satu representasi budaya, masyarakat atau kearifan lokalPapua yakni pohon sagu.Sagu merupakan makanan pokok bagi masyarakat Papua yang sudah turun temurun sejak nenek moyang mereka mengenal cocok tanam. Se-dangkan sagu terkait kearifkan lokal karena bukan hanya menjadi sumber bahan pangan pokok, tetapi tiap bagian pohonnya digunakan masyarakat untuk berbagai keperluan hidup, misalnya akarnya menjaga tata air batangnya untuk kayu hingga berbagai kera-jinan tangan, serta daunnya untuk atap rumah hingga makanan ternak dan obat.Lahan sagu juga mulai terganggu atau berkurang akibat berbagai kebijakan terkait pembangunan dan berbagai hal lainnya. Bah-kan, diprediksi sekitar 2.832 hektar lahan hutan sagu akan terkikis oleh pembangunan.10 Artinya, lahan yang tersisa tinggal 470,5 hektar di 6 distrik, Kabupaten Jayapura, Rincian potensi lahan yang hilang dari 6 distrik itu lebih dari 70\%.11 Di Distrik Sentani Barat dan Demta disebutkan potensi lahan sagu akan lenyap 100\%. Sementara di Sentani yang hutan sagunya pal-ing besar, prediksi kehilangannya juga besar menjadi 1.507 hektare atau terkikis hingga sekitar 77\%.12 Seka-lipun sudah ada regulasi Peraturan Pemerintah Daerah ( Perda) untuk mencegah terganggunya lahan atau hutan sagu yaitu Perda Kabupaten Jayapura Nomor 3 Tahun 2000 Tentang Pelestarian Kawasan Hutan Sagu dan Perda Propinsi Papua Nomor 27 Tahun 2013 tentang Perlindungan Lahan Pertanian Pangan Pokok Berkelanjutan, namun Peraturan tersebut tidak berjalan sesuai harapan.Demikian juga berkurangnya produksi pangan, diantaranya menyusutnya lahan dan tingginya kehilangan paska panen mengakibatkan tingginya ur-banisasi.Untuk menarik masyarakat kembali ke sagu sebagai penunjang untuk perekonomian, diperlukan modifikasi untuk dikaji lebih mendalam mengingat ketersediaan sagu 55\% sagu di dunia ada di Indonesai. Dan 50\% ada di Papua ini modal untuk ketahanan

\footnotetext{
10https:/www.gatra.com/detail/news/427554/economy/sagu-ketahanan-pangan-dan-kearifan-Iokal

11 Ibid

12 Ibid
}

pangan Indosesia.13

Pemberdayaan masyarakat sebagai salah satu poin kunci dalam mempercepat dalam pembangunan desa salah satu konsepnya adalah memperkuat akselerasi pemberdayaan masyarakat desa adalah dengan mengembangkan komunitas-komunitas masyarakat desa yang aktif dan kreatif. Komunitas itu akan memi-liki daya unggul lebih kuat dibanding hanya memberi pelatihan kepada aparat desa.Selain itu melalui alokasi dana desa dengan memberikan pelatihan pemangku kepentingan desa melalui Akademi Desa 4.0, serta memberikan inspirasi dalam pembangunan ekonomi kreatif di desa.14

Untuk mendukung Program Ekonomi Kreatif Desa sesuai dengan UU Desa diwajibkan menemu-kan model-model berpikir kreatif dan inovatif untuk membangun desa dalam model inovasi memberdayaan masyarakat dalam penanggulangan kemiskinan di berikan ke masyarakat desa melalui inovasi pendidikan, inovasi pemanfaatan lahan kosong, inovasi penataan pasar tradisional, inovasi berbasis desa atau kampung. Dengan demikian faktor-faktor yang signifikan yang mempengaruhi pemberdayaan masyarakat hukum adat (masyarakat desa) dalam mendukung Program Kreatif Desa sesuai dengan UU Desa yaitu komit-men bersama, kepempimpinan, reformasi peraturan, reformasi kelembagaan, pengakuan tentang kekuatan dan kelemahan yang di miliki daerah kawasan serta meningkatkan kapasitas sumber daya manusianya dalam pengeloaan administrasi keuangan desa agar dalam implementasi UU desa tidak mengalami kendala dan pelasanaannya harus diawasi agar tidak terjadi penyimpangan dan penyalahgunaan wewenang oleh oknum kelembagaan dan perangkat desa. Selain itu dapat dibentuk komunitas yang berkualitas di wilayah pedesaan untuk memberikan edukasi digital guna pengembangan usaha dan pemberdayaan masyarakat untuk membantu bisnis masyarakat dan pelaku usaha mikro kecil dan menengah (UMKM).

\footnotetext{
13 Ibid

14Infobanknews.com/ekonomi-kreatif-bisa-jadi-motor-pembangunan-pedesaan/
} 


\section{Kesimpulan dan Saran}

Bahwa untuk pemberdayaan masyarakat desa dalam mendukung Program Ekonomi Kreatif Desa yaitu menemukan model-model berpikir kreatif dan inovatif untuk membangun desa dalam model inovasi memberdayaan masyarakat dalam penanggulangan kemiskinan di berikan ke masyarakat desa melalui ino-vasi pendidikan, inovasi pemanfaatan lahan kosong, inovasi penataan pasar tradisional, inovasi berbasis desa atau kampung. dibentuk komunitas yang berkuali-tas di wilayah pedesaan untuk memberikan edukasi digital guna pengembangan usaha dan pemberdayaan masyarakat untuk membantu bisnis masyarakat dan pelaku usaha mikro kecil dan menengah (UMKM).

Dengan pendekatan pemberdayaan masyarakat Hukum Adat (Masyarakat Desa) Dalam Mendukung Program Ekonomi Kreatif Desa sesuai UU Desa Perlu pengawasan agar tidak terjai penyimpangan dan penyalahgunaan wewenang oleh oknum kelembagaan dan perangkat desa. Dengan pola pendekatan pemberdayaan masyarakat diharapkan sebagai subjek pembangunan ikut serta dan berpartisipasi aktif dalam pelaksanaan Program Ekonomi Kreatif Desa sesuai dengan UU Desa.

\section{DAFTAR PUSTAKA}

\section{Buku}

Laksanto Utomo, Hukum Adat, Depok, Rajawali Pers, 2017

Tim Penulis Iluni S-3 FH UI Sumbangan Pemikiran

Alumni Program Doktor Ilmu Hukum Universitas

Indonesia Diskursus Hukum unruk

Kesejahteraan Rakyat, Jakarta, Kencana, 2019

\section{Peraturan perundang-undangan}

Undang-Undang Dasar 1945 Republik Indonesia

Undang-undang Republik Indonesia Nomor 6 Tahun 2014 Tentang Desa

\section{Makalah}

Herman Soewardi, Koperasi (Suatu Kumpulan Maka-lah), (Bandung: (kopin, 1989), hIm.413).

Makalah Pro Justitia No.2 Tahun IX April

1991, Internet

http://www.aphi-net.com/konflik lisman vl 15/pdf/ 300masv-FINALE.pdf

www.kombinasi.net/kembangkan-ekonomi-kreatif-

brbasis-desa/

www. Berdesa.com/produk-desa-ekonomi-kreatif/

https:/www.gatra.com/detail/news/427554/economy/

sagu-ketahanan-pangan-dan-kearifan-Iokal

Infobanknews.com/ekonomi-kreatif-bisa-jadi-motor-

pembangunan-pedesaan/ 